\title{
Syncope and Prostate Cancer Ambivalent Case History
}

\author{
Alfonso Lagi* \\ Internal Medicine Unit, Villa Donatello Hospital, Italy
}

Submission: September 06, 2017; Published: September 14, 2017

*Corresponding author: Alfonso Lagi, Internal Medicine Unit, Villa Donatello Hospital, Via G. Mameli 44, Firenze-50131, Italy, Tel: 0039 055583182/ 0039 3386316900; Email: alfonso.lagi1@tin.it

Keywords: Syncope; Undetermined syncope; Vaso vagal syncope; Prostate cancer; Pulmonary embolism

\section{Introduction}

The title of the case report, suggesting an unlikely association, wants to be provocative. However there is a link. It is probably the first case described concerning an unusual association between syncope and prostate cancer biopsy.

Venous thromboembolism (VTE) is a well-established complication of each malignancy, despite autopsy and retrospective studies suggesting that cancers of the pancreas, lung and stomach are most strongly associated with thrombosis $[1,2]$. Population based studies have identified lung, colon and prostate cancers (PC) as having a high rate of VTE association [3]. Thrombotic events may in fact be the first presentation of occult cancer; $10 \%$ of idiopathic VTEs have an underlying identifiable malignancy. These can manifest as deep vein thrombosis or pulmonary embolus (PE) [1].

\section{Case History}

Here we present the case of a 72 y. o. man with prior coronary artery disease who underwent biopsy of a prostate lump that turned out to be malignant (Low-grade Gleason <7). After performing the biopsy, a distance of about 2 hours and in full wellness, the man suffered from vaso vagal syncope. The transient loss of consciousness was short, slowly establishment preceded by nausea and vomiting food. The patient fell to the ground and not placed any harm.

The high value of D-dimer (108000/L) led to perform a contrast enhanced CT of the pulmonary circulation. Thromboembolic clot was found in the right inferior lobe of the lung.

\section{Discussion}

The association between cancer and thrombosis is a wellknown relationship [1]. The pathogenic mechanisms include hypercoagulability due to activation of clotting by tumour cells, vessel-wall injury and stasis [2].
The relatively high incidence of occult prostate cancer in the general population is well documented, both from autopsy specimens and from samples extracted during prostatectomy for benign prostatic hyperplasia [4].

Prostate cancer is known to be associated with coagulopathy, commonly with an increased risk of VTE [5]. These tumours are more commonly lower grade (Gleason score<7) and encapsulated. The Danish study found that risk of VTE was $2.2 \%$ in subjects with prostate cancer vs. $1.3 \%$ of control. The 1-year VTE standardized rate among PC patients who had high comorbidity levels was 15 per 1000 person-years [6].

This case history is peculiar for many motivations:

a) Literature search found one case report only of PE associated with PC as the presenting feature [7].

b) PE is consequence of the prostate cancer associated with prostate biopsy. The complication never has been described because syncope following biopsy is judged as vaso-vagal syncope as consequence of stress and periprocedure occurrences (fasting, fear, medicines, emotions).

Within a large sample of patients, the overall rate of hospitalization due to the realization of a complication of prostate biopsy was $1 \%$ [8]. Hospitalisation is referred to urinary tract infection or fever, rectal bleeding, urinary retention and indirect complication (coronary syndromes and respiratory failure).

Vaso-vagal syncope after prostate biopsy can be respect as uncommon; in fact, cases are not reported in literature. An explanation is that they do not come to the medical consult being considered a benign phenomenon. If the VTE can be the first manifestation of cancer, this is not surprising. In this case the release of tissue thromboplastin may have been involved into starting thrombophilia. 
In light of a recent study, which underscores the role of an increased DD and high Wells score associated with syncope [9] you have to consider the event as a possible consequence of VTE. The advice is that syncope in the presence of cancer can be considered as a sign of pulmonary VTE and then sought and treated.

On the other side an alternative pathophysiological explanation of the events is possible. The incidence of cancerassociated VTE varies due to patient-related factors (e.g. thrombophilia, comorbidities, performance status, history of venous diseases), tumour-related factors (cancer site, stage, grade), and treatment-related factors (surgery, chemotherapy, biopsy). Furthermore, blood count parameters (platelets and leukocytes) and biomarkers (D-dimer) are predictive signs for the risk of VTE in cancer patients and have been used to enhance risk stratification. Evidence suggests that cancer itself is associated with a state of hypercoagulability, driven in part by the release of pro-coagulant factors, such as tissue factor, from malignant tissue as well as by inflammation-driven activation of endothelial cells, platelets, and leukocytes [10].

So, think that the man could have had an increased DD as effect of prostate neoplasia and that PE might be pre-existent to biopsy and syncope. In trials conducted in patients with unprovoked VTE with the aim of identifying the presence of an occult cancer PE isolated or associated with deep venous thrombosis it was very frequent, between half and $2 / 3$ of the cases [11-13]. So, the transient loss of consciousness could be explained as vasovagal syncope with the need to single out for PE.

\section{References}

1. Rosovsky R, Lee AY (2010) Evidence-based mini-review: should all patients with idiopathic venous thromboembolic events be screened extensively for occult malignancy?. Hematology Am Soc Hematol Educ Program 2010: 150-152.

2. Sørensen HT, Mellemkjaer L, Steffensen FH, Olsen JH, Nielsen GL (1998) The risk of a diagnosis of cancer after primary deep venous thrombosis or pulmonary embolism. N Engl J Med 338(17): 1169-1173.
3. Lee AY, Levine MN (2003) Venous thromboembolism and cancer: risks and outcomes. Circulation 107(23 Suppl 1): I17-I21.

4. Breslow N, Chan CW, Dhom G, Drury RA, Franks LM, et al. (1977) Latent carcinoma of prostate at autopsy in seven areas. The International Agency for Research on Cancer, Lyons, France. Int J Cancer 20(5): 680688.

5. Adamson AS, Francis JL, Witherow RO, Snell ME (1993) Coagulopathy in the prostate cancer patient: prevalence and clinical relevance. Ann $R$ Coll Surg Engl 75(2): 100-104.

6. Ording AG, Horváth-Puhó E, Lash TL, Ehrenstein V, Borre $\mathrm{M}$, et al. (2015) Prostate cancer, comorbidity, and the risk of venous thromboembolism: A cohort study of 44,035 Danish prostate cancer patients, 1995-2011. Cancer 121(20): 3692-3699.

7. Mukherjee SK, Panthagani A, Ramroop N, Al-Dujaily S (2012) Pulmonary embolus as a first presentation of occult metastatic prostate cancer. BMJ.

8. Tamarelle B, Perrin P, Devonec M, Paparel P, Ruffion A (2016) Hospitalization rate in relation to severe complications of transrectal prostate biopsy: About 2715 patients biopsied. Prog Urol 26(11-12): 628-634.

9. Prandoni P, Lensing AW, Prins MH, Ciammaichella M, Perlati M, et al. (2016) Prevalence of pulmonary embolism among patients hospitalized for syncope. N Engl J Med 375(16): 1524-1531.

10. Ay C, Pabinger I, Cohen AT (2017) Cancer-associated venous thromboembolism: Burden, mechanisms, and management. Thromb Haemost 117(2): 219-230.

11. Chauchard M, Benali K, Papo T, Sacre K (2014) Positron emission tomography combined with computed tomography as a screening tool for occult malignancy in patients with unprovoked venous thromboembolism: an observational study. Medicine (Baltimore) 93(21): e110.

12. Alfonso A, Redondo M, Rubio T, Del Olmo B, Wilhelmi PR, et al. (2013) Screening for occult malignancy with FDG-PET/CT in patients with unprovoked venous thromboembolism. Int I Cancer 133(9): 21572164

13.13. Prandoni $\mathrm{P}$, Bernardi E, Valle FD, Visonà $\mathrm{A}$, Tropeano $\mathrm{PF}$, et al (2016) Extensive computed tomography versus limited screening for detection of occult cancer in unprovoked venous thromboembolism: a multicenter, controlled, randomized clinical trial. Semin Thromb Hemost 42(8): 884-890.

\section{Your next submission with Juniper Publishers will reach you the below assets}

- Quality Editorial service

- Swift Peer Review

- Reprints availability

- E-prints Service

- Manuscript Podcast for convenient understanding

- Global attainment for your research

- Manuscript accessibility in different formats

( Pdf, E-pub, Full Text, Audio)

- Unceasing customer service

Track the below URL for one-step submission https://juniperpublishers.com/online-submission.php 